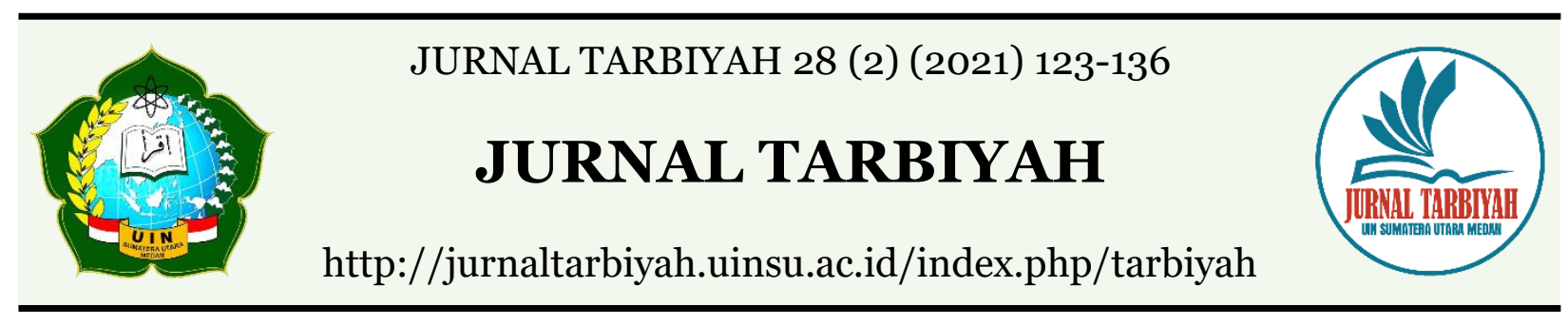

\title{
THE IMPLEMENTATION OF ONLINE LEARNING POLICY DURING THE COVID-19 PANDEMIC AT DHARMAWANGSA UNIVERSITY
}

\author{
Amini' ${ }^{1}$, Ainun Mardhiah², Akrim³ \\ 1,2,3 Universitas Muhammadiyah Sumatera Utara \\ Email:amini@umsu.ac.id, 2ainun280375@gmail.com, $\underline{\text { 3akrim@umsu.ac.id }}$
}

DOI : 10.30829/tar.v28i2.1139

Accepted: November 4th, 2021. Approved: December 28th, 2021. Published: December 30th, 2021

\begin{abstract}
This study aims to determine (1) to describe the online learning policy at Dharmawangsa University, (2) Describe and analyze the Implementation of Online Learning Policies During the COVID-19 Pandemic Period at Dharmawangsa University., (3) Describe whether there are any obstacles during the online learning process (4) Describe what inputs can be taken from student complaints about the online learning process at Dharmawangsa University. Data collection techniques in research using interview techniques and documentation. The data analysis technique used in this research is qualitative analysis through data reduction, data display, and conclusion drawing. The results of this study indicate that (1) Dharmawangsasudang University followed the instructions of the Ministry of Education and Culture SE No. 5 of 2020 and SE of Higher Education No. 1 of 2020 and was following these instructions. (2) Lecturers and teaching staff at Dharmawangasa University also know the Circular. However, it is not comprehensive (3) The implementation of online learning policies during the COVID-19 pandemic at Dharmawangsa University, most of the lecturers answered less effectively, especially when taking lessons where the courses required doing practicum or practice so that they could not run under learning outcomes. (4) There are significant obstacles when the online learning process is carried out, including uneven network connections in the student's residential area and insufficient internet quota in carrying out the online learning. (5) As for input from complaints submitted by students during the learning policy online during the pandemic, including uneven network connections and the lack of quotas owned by students.
\end{abstract}

Keyword: Policy Implementation, Online Learning, Covis 19 Pandemic Period. 


\section{INTRODUCTION}

The Coronavirus disease 2019 (COVID-19) outbreak presents challenges for educational institutions, especially universities. To fight COVID-19, the government has prohibited crowding, social distancing, and physical distancing, wearing masks, and constantly washing hands. The Ministry of Education and Culture has prohibited universities from conducting face-to-face (conventional) lectures and ordered them to hold lectures or online learning (Kemendikbud Dikti Circular No. 1 of 2020) and SE Kemendikbud No. 15 of 2020. Universities are guided to be able to organize online learning (Firman, F., \& Rahayu, S., 2020).

Various problems arise in education today, where all countries in the world are experiencing the COVID-19 pandemic. So the government implements various policies so that learning does not stop. Along with that, the development of science and technology is also no less advanced, so that it is easier for the government to take learning policies and implement them into the Online Learning system (in the network) at every level of education.

Of course, the pandemic outbreak due to the Coronavirus (COVID-19) spread has caused various panics in higher education. Campuses must house lecturers, staff, and students. Lectures, which usually are conducted face-to-face in class, have to change the format to online lectures.

Not a few universities quickly responded to government instructions, including Dharmawangsa University, by issuing a letter of instruction on preventing the coronavirus disease (COVID-19) within the University. In the circular, there are 10 points, and one of them is a recommendation to implement online learning (Yandwiputra, 2020).

Around 65 universities in Indonesia have implemented online learning in anticipation of the spread of COVID-19 (CNN Indonesia, 2020). Jamaluddin, D., Ratnasih, T., Gunawan, H., \& Paujiah, E. (2020) stated that online learning has its strengths, challenges, and obstacles.

The success of learning media is seen from a technical side and depends on each student. Nakayama M (2007) revealed that from all the literature in e-learning that not all students will be successful in online learning. It is because of the learning environment and the factors of each student. Learning at each University applies different forms and techniques. As for the output, many students do not understand the material, have more independent assignments and have difficulty doing practicum to support courses. Practicums that are carried out online are sometimes impossible to practice at home due 
to the limitations of tools and experimental samples. Lecturers are also more challenging to help students during bold learning because it is limited to the media, so there may be students who fall asleep when the lecturer delivers the material or students leave it to be present but are not listening. In addition, another problem with this bold learning is the limited internet signal in some areas, which hampers the learning process.

In the long term, online learning can limit field activities or practicums that support courses so that mixed learning innovation is needed / The government is also trying its best to support the continuity of learning during the COVID-19 pandemic, such as the example of providing quota subsidies for students, teachers, students, as well as lecturers every month. In the long term, online learning can limit field activities or practicums that support courses, so blended learning innovations (blended learning) are needed when conditions begin to improve and support health protocol protocols on campus.

\section{METHOD}

Judging from the type of data, the research approach used in this study is qualitative as for what is meant by qualitative research, namely, research that intends to understand the phenomena of what is experienced by research subjects holistically and utilizing descriptions in the form of words and language, in a particular natural context and by utilizing various scientific methods (Moleong, 2007:6).

This research approach was descriptive research. Descriptive research seeks to describe current problem solving based on data. The type of qualitative descriptive research used in this study was intended to obtain in-depth and comprehensive information on the implementation of online learning policies during the COVID-19 pandemic at Dharmawangsa University. In addition, the qualitative approach is expected to reveal the problems faced in this online learning activity.

\section{RESULTS AND DISCUSSION}

Based on the results of interviews that have been carried out, the researchers were able to find several facts related to the Implementation of Online Learning Policies During the COVID-19 Pandemic at Dharmawangsa University according to the follow-up of the research, namely the qualitative method in the form of: 
Regarding government instructions on online learning, here the researchers found that at Dharmawangsa University, all teaching staff had implemented an online learning system for their students after knowing the Circular about online learning.

The implementation of Learning From Home (BDR) during the COVID-19 emergency aims to:

1. Ensure the fulfillment of students' rights to obtain educational services during the COVID-19 emergency;

2. Protecting education unit residents from the adverse effects of COVID-19;

3. Preventing the spread and transmission of COVID-19 in education units;

4. Ensure the fulfillment of psychosocial support for educators, students, and parents/guardians.

The Principles of Implementation of Learning from Home. BDR is carried out by the principles contained in the Circular of the Minister of Education and Culture No. 15 of 2020 concerning the Implementation of Education Policies in the Emergency Period for the Spread of Corona Virus Disease (COVID 19), namely:

1. Safety and health are the primary considerations.

2. A meaningful learning experience without the demands of curriculum achievement;

3. Focus on life skills education

4. Learning materials are inclusive.

5. Activities and assignments during BDR may vary according to interests and conditions

6. Learning outcomes are qualitative without giving quantitative scores/values; and

7. Positive patterns of interaction and communication between teachers and parents/guardians.

Method of Implementation of Learning from Home (BDR)

BDR is implemented by Distance Learning (PJJ) which is divided into two approaches:

1. Online

2. Offline

In this regard, the Directorate General of Higher Education, Ministry of Education and Culture, will conduct a One-Year Survey of the Implementation of Online Learning as study material for the following online learning policy. We hope for the willingness of the entire academic community to support this survey activity and fill out the survey page, 
which can be accessed at: spada.kemdikbud.go.id/survey-pembelajaran-daring. Given the importance of the results of the online learning survey to map the readiness and strategic policies needed in the implementation of the Online Semester FY 2021/2022 in universities, the active participation of all components of higher education is highly appreciated. This survey will close on April 30, 2021.

In implementing online learning, Dharmawangsa University uses google classroom, google meet, and zoom meetings, but some lecturers rarely implement online learning using zoom meetings because of quota and network constraints for students and the lecturers themselves. Online learning time throughout the day adjusts to the availability of time, conditions, and agreements between students and their parents/guardians.

The online learning process consists of:

1. Virtual face-to-face via video conference, teleconference, and group discussion on social media or messaging applications.

2. Learning Management System (LMS). Examples of LMS include virtual home learning classes, google classroom, teacher's room, zenius, edmodo, moodle, seamolec LMS learning, and others.

3. Facilitate offline distance learning

The offline learning process can be carried out by:

a) Using books, modules, and teaching materials from the surrounding environment;

b) Using television media; and

c) Using radio

Online learning uses the internet network with accessibility, connectivity, flexibility, and the ability to bring up various types of learning interactions. Research conducted by Zhang et al. (2004) shows that the internet and multimedia technology can change the way knowledge is conveyed and can be an alternative to learning carried out in traditional classrooms. Online learning can bring together students and lecturers to carry out learning interactions with the help of the internet (Kuntarto, E. (2017). At the implementation level, online learning requires the support of mobile devices such as smartphones or Android phones, laptops, computers, tablets, and iPhones that can be used to access information anytime and anywhere (Gikas \& Grant, 2013). Universities during the WFH period need to carry out strengthening online learning (Darmalaksana, 
2020). Online learning has become a demand in education in the last few years $(\mathrm{He}, \mathrm{Xu}$, \& Kruck, 2014). Online learning is needed in learning in the era of the industrial revolution 4.o (Pangondian, R. A., Santosa, P. I., \& Nugroho, E., 2019). The use of mobile technology has a significant contribution to educational institutions, including achieving distance learning goals (Korucu \& Alkan, 2011). Various media can also be used to support the implementation of online learning. For example, virtual classes use Google Classroom, Edmodo, Schoology services (Enriquez, 2014; Sicat, 2015; Iftakhar, 2016), and instant messaging applications such as WhatsApp (So, 2016). Online learning can even be done through social media such as Facebook and Instagram (Kumar \& Nanda, 2018). Online learning connects students with learning resources (databases, experts/instructors, libraries) who are physically separated or even far apart but can communicate, interact, or collaborate (directly/synchronously and indirectly/asynchronously).

As for the implementation of online learning during the COVID-19 pandemic at Dharmawangsa University itself, it is a solution that currently wants or does not have to be implemented because this is a solution taken by the government to reduce crowds and also limit the spread of the COVID-19 virus, which is certainly good from the lecturers. or students have to adapt in following the learning process. Although some subject areas cannot be used online, for example, related to practicum and practical work, the campus arranges a shift system for students and lecturers by arranging meeting schedules for practical learning and practicum. There is nothing wrong with the online learning model during the COVID-19 pandemic or the New Normal because this learning model is easy to do, especially at this time. So it is just a matter of how to package this online learning to be more effective and work well; that is what has to be done.

Another challenge faced is the obstacle in financing online learning. Students revealed that they had to pay quite a lot of money to buy an internet data quota to participate in online learning. According to them, learning in video conferencing has consumed a lot of data quota, while online discussions through instant messaging applications do not require much quota. The average student spends Rp. 100,000 to Rp. 200,000 per week, depending on the cellular provider used. Online learning using video conferencing is quite expensive (Naserly, M. K., 2020). Although gadgets can support online learning, there are negative impacts that need attention and anticipation, namely excessive use of devices. They admit that students also use smartphones for social media and watching YouTube in addition to learning. Social media has entered the realm of early 
adult life (Lau, 2017). Students access social media in the context of self-expression, build friendship networks and opinions (Kim, Wang, \& Oh, 2016). Unfortunately, many people are addicted to gadgets due to using them excessively (Waslh, White \& Young, 2007). It is necessary to worry about entering misleading information and not paying attention during learning due to playing social media (Siddiqui \& Singh, 2016). In addition, students who are addicted to devices have academic and social problems (Kwon et al., 2013). Learners who have gadget addiction have emotional and behavioral problems (Asif, A. R., \& Rahmadi, F. A., 2017).

The online learning system (on the network) is a learning system without face-toface directly between teachers and students, which is carried out by utilizing the internet network. According to the author, this view is also inaccurate because not all lecturers are like that. Lecturers should be given guidance and provided with appropriate and suitable online learning models. I think the lecturers also want to learn in a more advanced direction. There is no need to make statements that lead to efforts to weaken the lecturer's position. Whether we realize it or not, our education system refers more to result from orientation and pursuing material targets, even though what needs to be improved is the basic foundations of education according to its level, namely the cultivation of character, skills, and intelligence. Should not be too pursuing the level of intelligence, but forget the character education. Because, if this continues, the foundation of education will collapse, children will become people with high egos regardless of the value of tolerance, mutual love, mutual assistance, and others. @masdzikry.com April 12, 2021, stated that there are 12 advantages and disadvantages of online learning; one of the advantages of online learning is that it can communicate without the need to meet in person, and the drawback is that it requires a stable internet connection. Therefore, to access online learning smoothly, you must use an internet connection that is more stable and faster: advantages and Disadvantages of Online Learning.

Below are some of the advantages and disadvantages of online or online learning that you need to know, including:
a. Unlimited distance.
b. Preventing the spread of the covid-19 virus
c. No need to bother to meet in person.
d. Many people can use free and.
e. Speed up the learning process, such as sending files, googling, etc.
f. Facilitate the process of interaction between lecturers and students. 
g. Continue to develop.

The Disadvantages of Online Learning are:

a. Requires a relatively fast and stable internet connection.

b. Requires a smart device like android or laptop, which is adequate.

c. For some students, online learning is complex and challenging to understand.

d. Can be misused for identity falsification, the absence of direct interaction that can hinder the learning process.

Online learning also has the advantage of being able to foster self-regulated learning. Online applications can increase independent learning (Oknisih, N., \& Suyoto, S., 2019). Kuo et al. (2014) stated that online learning is more student-centered, which causes them to create responsibility and autonomy in learning (learning autonomy). Online learning requires students to prepare their learning, evaluate, manage, and maintain motivation in learning (Sun, 2014; Aina, M., 2016). Sobron, A. N., \& Bayu, R. (2019) stated that online learning could increase student interest.

The obstacles faced by students or lecturers during the online learning process are obstacles related to the internet network, especially for students who are outside the region. It is tough to get a network, not to mention the obstacle that the existing internet quota is not sufficient to follow the learning process so that the lecturer only provides an online learning process using only google classroom because the lecturer thinks about the complaints that are conveyed. Not to mention the emotional constraints for lecturers towards their students, because students tend to be lazy and do not care about the tasks that the lecturer gives to their students, and also includes the constraints on student etiquette towards their lecturers being impolite.

The key to successful online learning is communication. Communication must be established between lecturers and students either through WA or other chats, so communication continues even through chat. Furthermore, in this case, the lecturer has prepared an online learning plan that will be implemented later. If the lesson plan has been prepared, then the success of the learning achievement will affect it. Structured learning that has been prepared should be systematic, and there is a contingency plan also when the plans drawn up do not meet the achievement criteria in learning so that lecturers are ready for obstacles that will occur when the online learning process is not optimal.

For example, if suddenly the lecturer does not get enough network, or there is an insufficient quota in the implementation of online learning by using classroom, zoom 
meeting, or google meet, the lecturer can use WA group to convey learning information, or even share learning videos. So that students feel the presence of their lecturers when the online learning process takes place, lecturers can also make learning recordings to respond to questions from students or students.

Effective online learning begins with planning and focuses on the needs of learning materials and the needs of students, so it is necessary to increase the competence of lecturers in designing online learning to make it more attractive in its presentation, especially in the field of teaching media. Suppose the lecturer presents teaching materials with exciting media. In that case, it will cause curiosity for students; it can also be said that teaching media also play an essential role in the attractiveness of learning which will later be presented during online learning in the form of an initial lighter in carrying out learning. The success of lecturers in conducting online learning in this COVID-19 pandemic situation is the ability of lecturers to innovate in designing and concocting materials with learning methods and what applications are appropriate. Creativity is the key to a lecturer's success to motivate students to remain enthusiastic in carrying out online learning.

\section{CONCLUSION}

Based on research findings, it can be concluded that:

1. Implementation of online learning during the COVID-19 pandemic at Dharmawangsa University itself is a solution that currently wants or does not have to be implemented because this is a solution taken by the government to reduce crowds and also limit the spread of the COVID-19 virus, which is certainly good from the lecturers or students have to adapt in following the learning process.

2. Regarding the Implementation of Learning Policies From the COVID-19 Pandemic Period at Dharmawangsa University, online learning is still carried out. The types of online learning implemented at Dharmawangsa University are in the form of google classroom, google meet, and zoom meetings, except only for exams and thesis examination, which is carried out face-to-face, also related to learning that requires carrying out practicum. However, it is made in shifts and a large room by keeping a distance and implementing the COVID-19 health protocols that the government has instructed.

3. Online learning at Dharmawangsa University is significantly less effective. Lecturers and students have to look for network sources and strong signals so that 
learning can occur, not to mention the problem of learning outcomes that are expected to be less achieved, even for the implementation of practicum or even practices requiring student competence according to to the majors taken. So that online learning cannot be fully implemented, the campus must make face-to-face learning to achieve competencies that require practice, although it does not rule out the fact that with this online learning, education implementers continue to be motivated to improve their knowledge in the field of digital technology for the better.

4. Dharmawangsa University increases student capacity and student competencies that are difficult to explore. Because of the mindset of students who do not want learning by using "blended learning" to improve their competence. On the one hand, we also realize that with the current government instructions for online learning, lecturers and students are inevitably indirectly demanded to become digitally literate. If lecturers carried out previous learning by blended learning with PPT media only and using Google during exams and doing assignments, lecturers and students can use the Zoom Meeting application and Google Meet to do faceto-face learning. Therefore, lecturers and students must learn to use it and share teaching materials in google classroom and present them through the application because the policies taken by the government must continue to be implemented even though the effectiveness of learning is not optimal to achieve learning outcomes.

The obstacles that become obstacles in the implementation of online learning policies are the internet network which is not optimal in certain areas, and also the limited quota owned by lecturers or students in conducting it due to the limited financial capabilities of students who are different, where parents must add additional funds for the demands for the implementation of the online learning.

\section{REFERENCES}

A. Kurniawati, dkk. 2013. Implementasi Metode Penugasan Analisis Video pada Materi Perkembangan Kognitif, Sosial dan Moral. Jurnal Pendidikan IPA Indonesia, Volume 2, Nomor 2.

Abdul Majid. 2014. Implementasi Kurikulum 2013. Bandung: Interes Media.

Agung, A. A. G. (2014). Metodelogi Penelitian Pendidikan. Malang: Aditya Media Publishing. 
Ahmadi, Lif Khoiru dan Sofan Amri. 2011. Paikem Gembrot. Jakarta: Prestasi Pustakarya.

Ali Sadikin. 2020. BIODIK: Jurnal Ilmiah Pendidikan Biologi Vol. 06, No. 02 (2020), Hal. $214-224218$

Allen, Michael. 2013. Michael Allen's Guide to E-learning. Canada: Jonh Willey \& Sons. Annur, M. F. (2020). Analisis kesulitan mahasiswa pendidikan matematika. Jurnal Kajian, Pnelitian Dan Pengembangan Kependidikan, 6356, 195-201.

Apriansyah, Sambowo, \& Maulana. (2020). Pengembangan Media Pembelajaran Video

Berbasis Animasi Mata Kuliah Ilmu Bahan Bangunan Di Program Studi Pendidikan

Teknik Bangunan Fakultas Teknik Universitas Negeri Jakarta. Jurnal Pendidikan Teknik Sipil (Jpensil), 9(1), 8-18. Retrieved from http://journal.unj.ac.id/unj/index.php/jpensil

Arifin, Zainal. 2013. Evaluasi Pembelajaran. Bandung: Remaja Rosdakarya.

Arifa, F. N. (2020). Tantangan Pelaksanaan Kebijakan Belajar Dari Rumah Dalam Masa Darurat COVID-19. Info Singkat; Kajian Singkat Terhadap Isu Aktual Dan Strategis, $\mathrm{XII}(7 / \mathrm{I}), 6$.

Arsyad, A. (2011). Media Pembelajaran. Jakarta: Rajawali Pers

Asnawir dan Basyiruddin Usman. 2002. Model Pembelajaran. Jakarta: Ciputat Pers.

Batubara, H. H., \& Batubara, D. S. (2020). Penggunaan Video Tutorial Untuk Mendukung

Pembelajaran Daring Di Masa Pandemi Virus Corona. Muallimuna: Jurnal Madrasah Ibtidaiyah, 5(2), 21. https://doi.org/10.31602/muallimuna.v5i2.2950

Chandrawati, Sri Rahayu. 2010. Pemanfaatan E-Learning Dalam Pembelajaran. Jurnal Cakrawala Kependidikan, Volume 8, Nomor 2.

Chaeruman, U. A. (2017). PEDATI Model Sistem Pembelajaran Blended, Panduan Merancang Mata Kuliah Daring, SPADA Indonesia.

Dailami. (2020). Jurnal Pendidikan IPS. Jurnal Pendidikan IPS.

Darmalaksana, W., Hambali, R. Y. A., Masrur, A., \& Muhlas. (2020). Analisis Pembelajaran Online Masa WFH Pandemic Covid-19 sebagai Tantangan Pemimpin Digital Abad 21. Karya Tulis Ilmiah (KTI) Masa Work From Home (WFH) Covid-19 UIN Sunan Gunung Djati Bandung Tahun 2020, 1(1), 1-12.

Darmawan, D. 2012. Pendidikan Teknologi Informasi dan Komunikasi. Bandung: Remaja Rosdakarya.

Daryanto dan Raharjo Muljo. 2012. Model Pembelajaran Inovatif. Yogyakarta: Gava Media. 
Dewi, Wahyu Aji Fatma. 2020. Dampak Covid-19 Terhadap Implementasi Pembelajaran Daring di Sekolah Dasar. Jurnal Ilmu Pendidikan, Volume 2, Nomor 1.

Dewi, W. A. F. (2020). Dampak COVID-19 terhadap Implementasi Pembelajaran Daring di Sekolah Dasar. Edukatif: Jurnal Ilmu Pendidikan, 2(1), 55-61. https://doi.org/10.31004/edukatif.v2i1.89

Effendi, Empy dan Hartono Zhuang. 2005. e-Learning Konsep dan Aplikasi. Yogyakarta: Andi.

Fathurrohman, Muhammad dan Sulistyorini. 2012. Implementasi Manajemen Peningkatan Lembaga Pendidikan Islam Secara Holistik. Yogyakarta: Teras.

Fitriyani, Y., Fauzi, I., \& Sari, M. Z. (2020). Motivasi Belajar Mahasiswa Pada Pembelajaran Daring Selama Pamdemic Covid-19. Jurnal Kependidikan, 6(2), 165175 .

Hamalik, Oemar. 2007. Dasar-Dasar Pengembangan Kurikulum. Bandung: Remaja Rosdakarya. Hamdani. 2011. Strategi Belajar Mengajar. Bandung: CV Pustaka Setia.

Hamdani, A. R., \& Priatna, A. (2020). Efektivitas Implementasi Pembelajaran Daring (Full Online) Dimasa Pandemi Covid-19. VI, 1-9.

Handayani, Hadi, Isbaniah, Burhan, \& Agustin. (2020). Corona Virus Disease 2019. Jurnal Respirologi Indonesia", 40(2). https://doi.org/https://doi.org/10.36497/jri.v40i2.101.

Harjanto. (2020). Tantangan dan Peluang Pembelajaran dalam Jaringan Studi Kasus Implementasi E-lok. Jurnal Pendidikan Dan Kebudayaan.

Haerul, Haedar Akib dan Hamdan. 2016. Implementasi Kebijakan Program Makassar Tidak Rantasa (MTR) di Kota Makassar. Jurnal Administrasi Publik, Volume 6, Nomor 2.

Herliandry, Enjelina, \& Kuswanto. (2020). Pembelajaran Pada Masa Pandemi Covid-19. Jurnal Teknologi Pendidikan, 22(1). Retrieved from https://doi.org/10.21009/jtp.v22i1.15286

Ibrahim, D. S., \& Suardiman, S. P. (2014). Pengaruh Penggunaan E-Learning Terhadap Motivasi dan Prestasi Belajar Matematika Siswa SDN Tahunan Yogyakarta. Jurnal Prima Edukasia, 2(1), 66 diakses pada 24 Agustus 2020.

Kemendikbud. (2020). Pedoman Penyelenggaraan Belajar dari Rumah Kurikulum Tingkat Satuan Pendidikan. Bandung: PT. Remaja Rosdakarya. 
Kemendikbud, D. G. (2016). Petunjuk Teknis Program Peningkatan Guru Pembelajar Muda dalam Jaringan.

Kuntarto, E. (2017). Keefektifan Model Pembelajaran Daring Dalam Perkuliahan Bahasa Indonesia di Perguruan tinggi. Journal Indonesian Language Education and Literature, 3(1), 53-65.

Mamud. (2011). Metode Penelitian Pendidikan. Bandung: Pustaka Setia.

Maulana, H. A., \& Hamidi, M. (2020). Persepsi Mahasiswa terhadap Pembelajaran

Daring pada Mata Kuliah Praktik di Pendidikan Vokasi. Equilibrium: Jurnal Pendidikan, 8(2), 224-231. https://doi.org/10.26618/equilibrium.v8i2.3443

Mona, N. (2020). Konsep Isolasi Dalam Jaringan Sosial Untuk Meminimalisasi Efek Contagious (Kasus Penyebaran Virus Corona Di Indonesia). Jurnal Sosial Humaniora Terapan, 2(2). https://doi.org/https://doi.org/10.7454/jsht.v2i2.86.

Mustakim. (2020). Efektivitas Pembelajaran Daring Menggunakan Media Online Selama Pandemi Covid-19 Pada Mata Pelajaran Matematika the Effectiveness of E-Learning Using Online Media During the Covid-19 Pandemic in Mathematics. Al Asma: Journal of Islamic Education, 2(1), 1-12.

Mustakim. (2020). Efektivitas Pembelajaran Daring Menggunakan Media Online Selama Pandemi Covid-19 pada Mata Pelajaran Matematika Journal. uinalauddin.ac.id/index.php/alasma/article/view/1364 6 diakses pada 23 Agustus 2020. Edukatif: Jurnal Ilmu Pendidikan Volume 2 Nomor 1 April 2020 Halm 55-61 Ningsih, S. (2019). Persepsi Mahasiswa Terhadap Pembelajaran Daring Pada Masa Pandemi Covid-19. 5(1), 31-37. https://doi.org/10.17977/umo31v7i22020p124

Oktavian, R. (2020). Efektivitas Pembelajaran Daring Terintegrasi di Era Pendidikan 4.o. Jurnal Pendidikan dan Ilmu Pengetahuan Vol.20 No.2

Sadikin, A., Hamidah, A., Pinang, K., Jl, M., Ma, J., Km, B. Indonesia, P. (2020). Pembelajaran Daring di Tengah Wabah Covid-19 (Online Learning in the Middle of the Covid-19 Pandemic). 6(1), 214-224.

Simatupang, N. I., Rejeki, S., Sitohang, I., Patricia, A., Simatupang, I. M., Pendidikan, P. Indonesia, K. (2020). Efektivitas Pelaksanaan Pengajaran Online Pada Masa Pandemi Covid-19 Dengan Metode Survey Sederhana.

Sobri, M., Nursaptini, N., \& Novitasari, S. (2020). Mewujudkan Kemandirian Belajar Melalui Pembelajaran Berbasis Daring Diperguruan Tinggi Pada Era Industri 4.o. Jurnal Pendidikan Glasser, 4(1), 64. https://doi.org/10.32529/glasser.v4i1.373 
Sudarsana, I. K., \& Lestari, N. G. A. M. Y. (2020). Perspektif Pendidikan. Denpasar: Katalog Dalam Terbitan.

Syarifudin. (2020). Implementasi Pembelajaran Daring Untuk Meningkatkan Mutu Pendidikan Sebagai Dampak Diterapkannya Sosial Distancing. Jurnal Pendidikan Dan Kebudayaan.

Taufik, A. (2015). Konsep dan Panduan Untuk Penelitian Sikap Kepribadian dan Perilaku. Jakarta: Kencana.

Uno, H.B, (2008). Perencanaan Pembelajaran. Jakarta: PT Bumi Aksara.

Wahyono, P., Husamah, H., \& Budi, A. S. (2020). Guru profesional di masa pandemi COVID-19: Review implementasi, tantangan, dan solusi pembelajaran daring. Jurnal Pendidikan Profesi Guru, 1(1), 51-65.

Wahyu Aji Fatma Dewi1 Universitas Kristen Satya

Widiyono, A. (2020). Efektifitas Perkuliahan Daring (Online) pada Mahasiswa PGSD di Saat Pandemi Covid 19. Jurnal Pendidikan, 8(2), 169-177. https://doi.org/10.36232/pendidikan.v8i2.458

Wulandari, Sudatha, \& Simamora. (2020). Pengembangan Pembelajaran Blended Pada Mata Kuliah Ahara Yoga Semester II di IHDN Denpasar. Jurnal Edutech Undiksha, 8(1), 1-15. https://doi.org/http://dx.doi.org/10.23887/jeu.v8i1.26459

Yunus, N. R., Rezki, A., Nabi, K., Saw, M., Wabah, M., \& Menular, P. (n.d.). Kebijakan Pemberlakuan Lockdown Sebagai Antisipasi Penyebaran Corona Virus Covid-19?

Zahra, A. S., \& Wijayanti, S. (2020). Efektivitas Pembelajaran Basis Online di IAIN Tulung Agung Dengan Adanya Kebijakan Phisical Distancing Era Pandemi Covid19Efektivitas Pembelajaran Basis Online di IAIN Tulung Agung Dengan Adanya Kebijakan Phisical Distancing Era Pandemi Covid-19. (2020). 8, 83-89.

Zhafira SM. (2020). Daring Sebagai Sarana Pembelajaran Selama Masa Karantina Covid19. $4, \quad 37-45 . \quad \mathrm{http}: / /$ perpus.iainsalatiga.ac.id/lemari/fg/free $/ \mathrm{pdf} /$ ?file $=$ http://perpus.iainsalatiga.ac.id/g/pdf/public/index.php/?pdf=9567/1/SKRIPSI\% 2OTIARA\%2OCI 